\title{
IMPLEMENTASI PENDIDIKAN IMAN ANAK MENURUT ULANGAN 6:1-9 DI GPDI ALFA OMEGA BANGSALSARI
}

\author{
Murni Hermawaty Sitanggang ${ }^{1}$, Ince Foeh ${ }^{2}$ \\ ${ }^{1}$ Universitas Jember \\ ${ }^{2}$ Sekolah Tinggi Alkitab Jember \\ 1Jl. Kalimantan 37 Kampus Tegalboto, Jember, Jawa Timur \\ 2Jl. Letjend. Soeprapto VI/85-86, Jember, Jawa Timur \\ Email:murni_hermawaty@yahoo.co.id,1,marinchenokas@gmail.com²
}

\begin{abstract}
ABSTRAK: Orang tua memiliki tanggung jawab bukan sekadar memenuhi kebutuhan anakanak mereka melainkan juga mendidik mereka di dalam iman. Akan tetapi, masih banyak orang tua yang kurang memahami apa dan bagaimana pendidikan iman tersebut seharusnya dilakukan. Itu sebabnya di dalam tulisan ini penulis mengeksplorasi pendidikan iman anak di dalam keluarga dengan orang tua sebagai pendidik menurut Ulangan 6:1-9. Penulisan dilakukan dengan metode kualitatif dengan pendekatan deskriptif di GPdI Alfa Omega Bangsalsari. Penulis memilih delapan orang tua dari antara jemaat di sana sebagai partisipan dalam penulisan ini. Hasil yang didapat menunjukkan bahwa semua partisipan menyadari tanggung jawab mereka dalam mendidik anak. Namun pengetahuan tersebut masih bersifat mendasar dan perlu adanya pembekalan lebih lanjut.
\end{abstract}

Kata Kunci: anak; keluarga; orang tua; pendidikan iman; ulangan 6

\section{THE IMPLEMENTATION OF FAITH EDUCATION ACCORDING TO DEUTERONOMY 6:1-9 AT PENTECOSTAL CHURCH OF ALFA OMEGA BANGSALSARI}

\begin{abstract}
Parents have responsibilities to educate their children in faith besides supplying everything they need in life. However, there still are parents who are not ready and do not understand what and how to do education. Thus, this article will explore children nurturing faith in the family with their parents as the educator according to Deuteronomy 6:1-9. The research was conducted with a qualitative descriptive method at Indonesian Pentecostal Church Alfa Omega, Bangsalsari. There were eight parents at that church the author chose to participate in this research. The result shows participants are aware of their responsibility to educate their children. However, their knowledge is still in primary forms. Therefore, they need to be educated on how to do their role properly.
\end{abstract}

Keywords: children; family; parents; faith education; denteronomy 6 


\section{PENDAHULUAN}

Semua orang dapat memiliki anak, tetapi tidak semua orang dapat menjadi orang tua karena menjadi orang tua bukanlah hal yang mudah. Ada tanggung jawab yang besar yang harus dipikul ketika seseorang atau sepasang suami istri menjadi orang tua, yakni mendidik anak-anak dalam semua aspek, terutama iman. Tanggung jawab ini bukanlah sesuatu yang dapat dialihkan ke pihak lain, seperti kepada guru di sekolah atau pendeta di gereja, melainkan sesuatu yang menjadi bagian integral dalam kehidupan setiap orang tua (Mardiharto, 2019, p. 24). Orang tualah yang seharusnya menjadi yang pertama mengenalkan Tuhan Yesus Kristus kepada anak-anak mereka.

Salah satu bagian Alkitab yang popular sebagai dasar pendidikan iman anak dalam keluarga adalah Ulangan 6:1-9 (Darmawan, 2019, p. 21). Di dalam ayat-ayat tersebut Musa memberi nasihat kepada para orang tua bangsa Israel untuk mengajar anak-anak mereka untuk takut akan Tuhan Allah, taat pada perintah dan peraturan Tuhan Allah, setia kepada Tuhan Allah dengan tidak mengikuti ilah lain, mengasihi Tuhan Allah dengan segenap jiwa dengan segenap hati dan dengan segenap kekuatan.

Secara implisit Ulangan 6 menyatakan pembentukan iman anak bukanlah sesuatu yang dapat diupayakan dalam waktu singkat. Oleh sebab itu, ayat-ayat ini merupakan panggilan agar orang tua mengajar anak-anak mereka sejak usia dini dengan menjadikan rumah sebagai tempat pendidikan iman karena iman pada dasarnya bukan "diajarkan" melainkan "ditangkap" (Bunge, 2009). Maksudnya adalah anak-anak tidak sekadar membutuhkan pengajaran tetapi mereka perlu menangkap pembelajaran tersebut sebagai bagian dari praktik hidup sehari-hari.

Yang menjadi masalah adalah sering kali orang tua kurang memahami atau tidak menyadari tanggung jawabnya untuk mendidik anak-anaknya bertumbuh dalam iman. Masih ada orang tua yang menganggap tugas mengajar anak sepenuhnya ada di tangan guruguru Sekolah Minggu dan pendeta di gereja serta guru-guru di sekolah (Rantesalu, 2018, p. 154). Karena sibuk dengan pekerjaan, orang tua cenderung menurunkan standar dan berharap gereja dan sekolah dapat menutupi kekurangan pengajaran yang seharusnya anakanak dapatkan di rumah (Gregor, 2013, p. 116). Kurangnya pemahaman tentang peran orang tua dalam pendidikan anak juga menjadi temuan penelitian lapangan yang dilakukan oleh Nandari Prastica Wagiu di GMIM Bitung. Sekitar $50 \%$ dari informan penulisan mengira tempat utama anak mendapat pengajaran tentang iman adalah gereja, sekolah, dan sekolah tinggi teologi (Wagiu, 2020, p. 145).

Meskipun anak mungkin lebih banyak menghabiskan waktu di sekolah (setidaknya sebelum masa pandemi terjadi) daripada di rumah, tetap saja peran guru tidak dapat menggantikan orang tua. Keluarga sepatutnya menjadi tempat pelatihan karakter iman, kejujuran, kesetiaan, dan kemampuan-kemampuan penting lainnya untuk mampu menjalani hidup (Pantan \& Benyamin, 2020, p. 14). Pentingnya peran orang tua dalam pendidikan anak semakin terasa sekarang saat Indonesia mengalami pandemi, yang membuat sekolah tidak dapat berfungsi $100 \%$ dan anak-anak kemudian menghabiskan waktu lebih banyak di rumah. Tidak sedikit orang tua yang tidak siap dan kewalahan dengan hal ini karena tidak terbiasa mengurusi pendidikan anak-anaknya (Ismaniar \& Setiyo, 2020, p. 147). Padahal bila orang tua sudah terbiasa mendidik anak-anaknya, hal ini seharusnya tidak menjadi masalah besar.

Menyadari masalah pendidikan anak dalam keluarga selalu relevan karena berkenaan dengan pergumulan hidup sehari-hari menjadi alasan yang melatarbelakangi penulis tertarik mengkaji pendidikan anak oleh orang tua menurut Ulangan 6:1-9. Memang topik ini bukan hal yang baru. Ninik Tri Utami sebelumnya telah melakukan penelitian serupa 
yang murni berdasarkan kajian literatur untuk menemukan prinsip-prinsip pendidikan anak menurut Ulangan 6 (Utami, 2017). Kajian literatur lainnya dengan pola pendekatan hermeneutik terhadap Ulangan 6 juga telah dikerjakan oleh Syani Rantesalu (2018). Ulangan 6 juga menjadi dasar tulisan I Putu Ayub Darmawan, hanya saja ia tidak menitikberatkan soal pendidikan dalam keluarga tetapi membahas soal metode pembelajaran memorisasi (Darmawan, 2019). Penulisan artikel ini bermaksud memperkaya literatur yang telah ada dengan memaparkan hasil penelitian lapangan. Sebagaimana telah disinggung sebelumnya, telah ada tulisan yang berdasarkan penelitian lapangan yang dikerjakan oleh Nanda Prastica Waigu di Minahasa (Wagiu, 2020). Akan tetapi, mengingat salah satu komponen penting dari penelitian lapangan adalah fokus pada interpretasi dan makna (Martana, 2006) maka tidak ada penelitian lapangan yang hasilnya benar-benar sama. Selain adanya perbedaan lokasi penelitian dilakukan dengan penelitian sebelumnya, penelitian ini juga melibatkan partisipan berbeda, yang khusus adalah orang tua (sedangkan Wagiu melibatkan juga pendeta, penatua dan anak selain orang tua) untuk menghasilkan temuan yang lebih fokus. Adapun tujuannya adalah untuk melihat seperti apa pemahaman narasumber terhadap pendidikan anak menurut Ulangan 6. Penulis meyakini pemahaman yang benar terhadap Ulangan 6:19 dapat menolong orang tua untuk maksimal dalam mendidik anak-anaknya.

\section{METODE}

Metode penulisan yang digunakan pada penulisan ini adalah metode kualitatif deskriptif. Penulisan deskriptif menurut Ranjit Kumar adalah penulisan yang berusaha menggambarkan secara sistematis suatu situasi, problema, fenomena, program atau pelayanan (Kumar, 2011, p. 88). Tujuannya untuk memberikan informasi tentang kondisi kehidupan suatu komunitas atau menggambarkan sikap terhadap suatu isu.

Penelitian ini dilakukan di GPdI "Alfa Omega" Bangsalsari Kecamatan Bangsalsari Kabupaten Jember, Jawa Timur. Tahapan awal penulisan yang penulis lakukan adalah mengumpulkan data dari berbagai buku dan referensi tafsiran Ulangan 6:1-19 sebagai dasar argumen pendidikan anak. Setelah itu, langkah selanjutnya yang penulis kerjakan adalah mengumpulkan data melalui observasi dan wawancara di lokasi penelitian. Penulis memilih 8 (delapan) orang tua dengan rentang usia 4054 tahun untuk diwawancara lebih lanjut secara terstruktur. Mengingat jumlah orang tua anak sekolah Minggu di gereja tersebut hanya sekitar 35 pasang, penulis menganggap kedelapan orang tersebut sudah cukup mewakili keseluruhan. Penulis juga sengaja memilih para orang tua yang sudah berusia matang dengan pertimbangan mereka lebih berpengalaman dalam mengasuh anak daripada para orang tua muda. Karena penulisan diadakan pada masa pandemi maka wawancara dilakukan secara tertulis. Penulis menyebarkan pertanyaan yang sama kepada seluruh partisipan dan mereka kemudian mengembalikannya kepada penulis. Data yang didapat dari hasil wawancara tersebut kemudian dianalisis untuk kemudian direduksi, disajikan, dan disimpulkan.

\section{HASIL DAN PEMBAHASAN}

\section{Pendidikan Iman Secara Umum}

Istilah "pendidikan iman" terdiri dari dua kata penting "pendidikan" dan "iman." Kata "pendidikan" dalam bahasa Inggris adalah education, yang berasal dari bahasa Latin educationem yang berarti "pelatihan." Robert Pazmiño mendefinisikan education atau pendidikan sebagai proses berbagi pengetahuan dengan seseorang dalam konteks komunitas dan masyarakat (Pazmiño, 2010, p. 359). Di dalam proses ini ada terdapat tiga elemen penting yang saling berkaitan, yakni: konten, 
orang, dan konteks. Konten berbicara tentang informasi, sedangkan orang mengacu pada formasi, dan konteks berkenaan dengan transformasi (Pazmiño, 2010, p. 359). Dengan demikian ia mendefinisikan pendidikan Kristen sebagai pendidikan iman yang membagikan pengetahuan, nilai-nilai, sikap, keahlian, sensitivitas, dan tingkah laku yang sesuai dengan iman Kristen secara sengaja, sistematis, dan berkelanjutan (Pazmiño, 2010, p. 359). Jadi, pendidikan iman bukan hanya sekadar berbicara soal teori melainkan sesuatu yang mencakup cara hidup dan cara berpikir dalam mengambil keputusan. Anak tidak hanya perlu dituntun untuk tahu dan hafal Alkitab, tetapi mereka juga perlu belajar mengaplikasinya dalam setiap aspek kehidupan.

Iman di dalam Alkitab merupakan dasar dari segala sesuatu yang tidak kita harapkan dan bukti dari segala sesuatu yang tidak kita lihat (Ibr. 11:1). Menurut Easton's Bible Dictionary iman atau faith juga dapat diartikan sebagai meyakini suatu pernyataan sebagai kebenaran, yang tumbuh sebagai hasil dari pengajaran (Rm. 10:14-17) (Easton, n.d.). Oleh sebab itu, pengetahuan memiliki posisi penting dalam iman dan sering kali disamakan dengan iman itu sendiri (Yoh. 10:38; 1 Yoh. 2:3). Pusat dari pengetahuan tersebut adalah karya penyelamatan Allah yang dinyatakan melalui pengorbanan Yesus Kristus untuk menyelamatkan manusia.

Jadi, kita dapat menyimpulkan pendidikan iman sebagai proses berbagi pengetahuan tentang kebenaran yang berpusat kepada karya penyelamatan Allah di dalam Yesus Kristus. Sumber dari pendidikan iman tersebut tak lain adalah Alkitab. Kemudian menanggapi pertanyaan tentang di manakah sepatutnya seorang anak mendapatkan pendidikan iman, jawabannya adalah di dalam keluarga, baik keluarga jasmani maupun keluarga secara rohani. Keluarga jasmani mengacu kepada keluarga inti, yang terdiri dari ayah, ibu, saudara, yang dijumpai seyogyanya dijumpai seorang anak saat ia dilahirkan. Sedangkan keluarga rohani tentunya adalah tempat di mana seorang anak dan keluarganya beribadah dalam lingkup persekutuan saudara seiman, yakni gereja.

Dalam pendidikan iman kebutuhan utama seorang anak adalah kasih dan keamanan, yang menjadi tanggung jawab utama orang tua. Maksudnya di sini adalah orang tua bertindak dalam mengekspresikan cinta terhadap anak-anaknya dengan memenuhi kebutuhan dan menyediakan waktu untuk mereka. Selain itu, cara hidup dan keteladanan orang tua bahkan lebih penting daripada sekadar ucapan atau pendidikan secara verbal. Orang tua yang saling mengasihi satu sama lain dan yang mengasihi juga anak-anaknya akan memberikan rasa aman kepada anak (Gregor, 2013, p. 117).

Agar pendidikan dapat berjalan maksimal, kebutuhan dasar seorang anak haruslah terpenuhi terlebih dahulu. Selain kebutuhan primer seperti makanan, pakaian dan tempat tinggal, rasa aman adalah kebutuhan esensial semua umat manusia. Rumah dan keluarga sepatutnya menjadi tempat di mana seorang anak merasa berharga, dikasihi oleh Allah dan keluarganya sebagaimana adanya ia (Gregor, 2013, p. 118). Anak yang merasa aman dan dikasihi akan lebih mudah menyerap pendidikan iman dari orang tuanya. Setelah kebutuhan utama ini terpenuhi, anak siap untuk memasuki tahapan selanjutnya. Pedoman yang jelas tentang bagaimana sepatutnya pendidikan iman tersebut dilakukan di dalam lingkup keluarga dapat kita pelajari dari Ulangan 6:1-9 yang akan diterangkan berikut ini. 


\section{Pendidikan Iman oleh Orang Tua Menurut Kitab Ulangan 6:1-9}

\section{Latar Belakang Kitab Ulangan}

Karena bersifat laporan, penulis kitab Ulangan diyakini adalah Musa (1:5). Namun, dengan adanya pasal 34 yang mencatat kematiannya, ada asumsi tentang kemungkinan adanya penulis lain (34:5) (Grisanti, 2012, p. 45). Kita bahkan tanpa perlu melihat hingga ke pasal 34, sudah menemukan dari pasal 1 bagaimana penulis kitab ini memosisikan Musa sebagai orang ketiga (1:1-5) (Biddle, 2003, p. 4). Hal ini memunculkan kesadaran di kalangan sarjana Yahudi bahwa ada penulis lain yang membantu Musa dalam mencatat kitab ini. Ditambah lagi dengan catatan tentang kematian Musa di dalam pasal 34, yang jelas-jelas tidak mungkin dituliskan olehnya sendiri. Akan tetapi, kalaupun ada kemungkinan penulis lain yang membantu Musa dalam menulis kitab ini, beberapa kitab PL mengakui Musa sebagai penulisnya (Yos. 1:7; 8:31-32; 23:6; 1 Raj. 14:6; Neh. 8:1; 13:1; 2 Taw. 25:4; 35:12 dst.) (Grisanti, 2012, p. 45). Jadi, Musa tetap dapat kita anggap sebagai penulis kitab ini. Hanya saja, dalam prosesnya ia tampaknya dibantu oleh seorang sekretaris, yang menulis persis sesuai arahannya.

Musa mengalamatkan kitab Ulangan ini kepada bangsa Israel generasi kedua dan kepada Yosua yang akan menjadi pemimpin mereka agar mereka tetap setia kepada Tuhan Allah yang telah membawa dalam perjalanan mereka keluar dari tanah Mesir (Ludji, 2009, p. 110-111). Di dalam pasal 4, Musa mengngatkan bangsa Israel untuk memelihara Hukum Allah, dan mendorong mereka untuk mengabdikan kembali hidup mereka untuk Tuhan Allah. Hal ini diperkuat oleh judul kitab ini yang adalah Deuteronomy dalam bahasa Inggrisnya, mengacu kepada Ulangan 17:18, yang berisi peringatan agar raja Israel di masa mendatang menulis "salinan hukum" yang Tuhan berikan (atau ditulis a copy of this law di dalam Alkitab KJV) (Woods, 2011, p. 26). Istilah Deuteronomy itu sendiri berasal dari Septuaginta deuteronomos dan Vulgata deuteronomium, yang dapat diterjemahkan sebagai "hukum kedua" atau "hukum yang diulang." Akan tetapi, judul tersebut dianggap kurang tepat oleh para teolog mengingat kitab Ulangan sama sekali bukan replika dari kitab Keluaran hingga Bilangan (Grisanti, 2012, p. 47). Musa tidak menulis kitab Ulangan ini hanya sebagai kumpulan hukum atau catatan sejarah tetapi sebagai catatan pesan perkataan atau nasihatnya kepada bangsa Israel. Namun, meski mengakui kitab ini memang bukan berisi hukum kedua, Mark Biddle beranggapan nama tersebut tidak sepenuhnya salah sebab substansi dari kitab ini adalah penjelasan tentang perjanjian Sinai (Biddle, 2003, p. 4). Gaya penulisannya bersifat menegur di mana Musa sebagai orator mendorong jemaat Israel, yang berada di bawah kepemimpinannya, untuk taat dan berkomitmen terhadap Allah. Dengan demikian selain sebagai literatur, kitab Ulangan ini juga merupakan buku catatan perkataan yang telah diucapkan (Craigie, 1976).

Musa memulai kitab ini dengan mengulang kisah saat Israel berkemah di Sinai hingga saat mereka di dataran Moab. Ia melakukannya dengan tujuan untuk mengingatkan Israel bahwa Allah adalah pemelihara, pelindung, dan penebus mereka. Kemudian mulai dari pasal 5 hingga pasal 26, Musa mengingatkan Israel akan apa yang Tuhan perintahkan di masa akan datang dan pentingnya bagi mereka untuk taat. Ulangan pasal 6 yang akan penulis bahas berikut ini merupakan perkenalan ketiga terhadap peraturan-peraturan yang terdapat di dalam pasal 12-26 (Biddle, 2003, p. 124). Agar lebih terarah, penulis akan membagi pembahasan tentang pendidikan iman anak menurut Ulangan 6:1-9 ini menjadi dua bagian, yakni konten dan metode. 
Konten Pendidikan Iman Menurut Ulangan 6:1-9 dalam Relasi dengan Tuhan

\section{Takut akan Tuhan Allahmu (ay. 1-2)}

Ulangan pasal 6 dimulai dengan frasa "inilah perintah," yakni ketetapan dan peraturan, yang disebut juga dengan triad, yang dalam bahasa Ibraninya ditulis hammiswa habuqqim wehammispatim. Dalam kitab ini kata "perintah" atau mitswa muncul empat puluh tiga kali, ketetapan atau huqqim dua puluh satu kali, dan peraturan atau mispatim sebanyak tiga puluh tujuh kali. Frasa ini "inilah perintah" menyatakan keseluruhan kesatuan perintah Allah atau meringkas keseluruhan perintah Allah menjadi satu unit (Grisanti, 2012, p. 300). Ayat ini merupakan deklarasi akan perintah, statuta, atau ketetapan Allah yang disampaikan Musa dalam ayat-ayat selanjutnya. Ketetapan ini merupakan aturan, hukum, atau pedoman yang Allah berikan kepada Israel untuk dijadikan patokan bertindak dalam kehidupan sehari-hari di Kanaan, tempat yang mereka tuju. Tuhan tidak pernah menghendaki ketetapan-Nya sebagai pengajaran yang bersifat esoterik, yang sulit dimengerti, tetapi Ia menginginkan umat-Nya memahami hukum tersebut dan menjalankannya dalam kehidupan sehari-hari (Biddle, 2003, p. 124).

Ketika orang percaya mengenal Allah yang hidup, ia perlu menjadi takut. Ketakutan yang dimaksud di sini adalah kegentaran yang kudus, yang berasal dari Allah. Kegentaran tersebutlah yang mengantar orang percaya menjadi takut sekaligus menghormati kekuasaan Allah dengan patuh terhadap semua ketentuan-Nya, dan menjauhkan diri dari semua yang Ia larang (Yer. 32:40). Takut akan Tuhan itu merupakan permulaan hikmat (Ams. 1:7; Mzm. 111:10), menjauhkan orang dari kejahatan (Ams. 8:13), membuat Allah senang (Mzm. 147:11), dan kewajiban setiap orang (Pkh. 12:13). Jadi, takut yang dimaksud dalam ayat ini adalah rasa takut dan hormat terhadap kuasa Allah. Hal ini sepatutnya menjadi landasan dalam setiap aspek kehidupan umat Tuhan. Setiap pengambilan keputusan dan setiap tindakan haruslah dengan mempertimbangkan aspek apakah keputusan dan tindakan tersebut berkenan kepada Tuhan dan memuliakan-Nya.

Takut akan Tuhan bukan hanya merupakan tanggung jawab pribadi, melainkan juga komunal. Pada masa itu tanggung jawab komunitas merupakan kelaziman bagi orang Israel. Mereka menganggap seorang anak bukan saja cermin daripada orang tuanya melainkan juga komunitas tempat ia dibesarkan (Biddle, 2003, p. 29). Oleh sebab itu, umat Israel memiliki tanggung jawab bersama dalam menanamkan rasa takut tersebut kepada generasi penerus atau anak-anak mereka. Dengan melakukan hal ini secara turun temurun maka generasi mendatang akan terpelihara dengan sendirinya di dalam iman.

\section{Mempercayai Janji Tuhan (ay. 3)}

Ayat ini berisi seruan agar Israel mendengar perkataan Tuhan. Mereka bukan saja perlu mendengar, melainkan juga harus mempelajari dan melakukannya. Ketaatan yang sejati lahir ketika umat memahami perkataan Tuhan dan mengimaninya lalu kemudian menampakkan pemahaman mereka dalam kesetiaan mengerjakan perintah Tuhan dalam kehidupan sehari-hari. Ketika mereka melakukan ini maka mereka dapat mengharapkan janji berkat Tuhan (kesehatan, umur panjang, keturunan, dan berkat-berkat jasmani lainnya). Janji dapat diartikan sebagai persetujuan yang melibatkan dua pihak, dalam hal ini antara Allah dengan Israel. Janji ini juga berisi pemberitahuan untuk mengantisipasi kejadian di masa depan. Di dalam ayat ini Tuhan menjanjikan tanah yang penuh susu dan madu. Janji ini kemudian diulangi di dalam Ulangan 11:9; 26:9, 15; 27:3; 31:20. Tuhan tidak sekadar menjanjikan tanah atau negeri untuk mereka diami, tetapi negeri tersebut juga penuh susu 
dan madu, yang berarti negeri yang makmur (Craigie, 1976, p. 250). Dengan janji ini Tuhan meyakinkan umat-Nya bahwa Ia senantiasa memelihara mereka.

\section{Mempercayai Tuhan Allah itu Esa (ay. 4)}

Ayat ini berisi kebenaran fundamental tentang hakikat Allah yang monoteis (Craigie, 1976, p. 251). Yang harus didengar dan diperhatikan oleh bangsa Israel adalah fakta bahwa Allah yang mereka sembah itu esa. Implikasi teologis dari ayat ini adalah meski ada banyak ilah yang disembah oleh bangsa-bangsa lain saat itu, Allah Israel adalah bukan saja yang pertama, melainkan satu-satunya Allah Yang Maha Kuasa (Craigie, 1976, p. 251).

Ayat 4 ini kemudian menjadi fondasi ayat 5-9 dan hal ini menyatakan dengan jelas bahwa yang utama bukanlah hukum atau peraturan yang diberikan, melainkan si Pemberi aturan, yang adalah Allah itu sendiri (Hamilton, 2010, p. 13). Fokus daripada ayat ini pada dasarnya adalah relasi antara Allah dengan umat-Nya (Harris, 2016, p. 330). Dengan deklarasi ini Allah mengundang umat-Nya untuk terlibat dalam hubungan yang dekat dengan-Nya.

Kebenaran akan keesaan Allah ini memiliki dua implikasi penting bagi umat Tuhan, yaitu: implikasi praktis dan teologis (Craigie, 1976, p. 252). Secara praktis ayat ini berarti tidak ada kuasa lain yang setara dengan kuasa Allah dan ini telah dirasakan oleh bangsa Israel ketika mereka keluar dari Mesir. Hal itu dapat terjadi karena kuasa Allah lebih besar daripada ilah-ilah orang Mesir. Sedangkan implikasi teologis dari ayat ini adalah Allah bukan saja unique atau unik melainkan juga unity atau satu kesatuan. Sebagai Allah yang Esa, saat Ia berbicara, tak ada pihak yang menentang; ketika Ia berjanji, tidak ada yang membatalkan (Craigie, 1976, p. 252). Dengan kata lain, keesaan Allah merupakan jaminan kemahakuasaan Allah. Kita tak dapat mempercayai kemahakuasaan-Nya tanpa meyakini keesaanNya.

\section{Mengasihi Tuhan segenap hati, jiwa, kekuatan (ay. 5)}

Selain dikenal sebagai shema, ayat ini juga dianggap sebagai pusat dari kitab Ulangan (Craigie, 1976, p. 254).Seperti yang telah disinggung sebelumnya, tujuan kitab ini ditulis memperbaharui perjanjian dengan Allah. Untuk itu dapat terjadi, diperlukan ketaatan dari umat Tuhan. Ketaatan yang diharapkan adalah ketaatan yang keluar sebagai ekspresi kasih.

Hanya dengan ketaatan seseorang dapat mengasihi Tuhan dengan segenap kekuatan yang ada padanya. Frasa "dengan segenap hati" berarti semua umat-Nya sepatutnya melakukan segala sesuatu dengan didasarkan kasih kepada Allah (Hamilton, 2010, p. 14). Orang Ibrani memandang hati sebagai pusat dari pikiran dan kehendak, sedangkan jiwa merupakan sumber dari vitalitas kehidupan. Kata "hatimu" di dalam ayat ini berasal dari kata dasar lebab, yang oleh NAS Exhaustive Concordance diterjemahkan sebagai "bagian terdalam dari manusia, pikiran, kehendak, dan hati” (3842. Lebab, n.d.). Hati dan jiwa yang dikombinasikan dengan kekuatan menyatakan komitmen total umat Tuhan untuk mengasihi Allah (Andor \& Quaye, 2014, p. 144). Pentingnya ajaran ini kemudian ditegaskan oleh Yesus sendiri di dalam Matius 22:37 sebagai hukum yang pertama dan yang terutama, yang menjadi dasar seluruh hukum Taurat dan Kitab para nabi.

\section{Metode Pendidikan Iman}

\section{Mengajarkannya berulang-ulang (ay. 6-7)}

Frasa "berulang-ulang" di dalam ayat ini memakai kata shanan dalam bahasa Ibraninya, yang dapat diartikan sebagai mengajar dengan rajin. Ini berarti menekankan suatu proses penanaman ajaran secara terus-menerus, yang meliputi seluruh aspek kehidupan, baik saat duduk di rumah, maupun saat dalam perjalanan, saat berbaring dan juga saat bangun. 
Empat kondisi tersebut mengindikasikan pengajaran tidak memandang tempat dan waktu atau dengan kata lain, harus disampaikan setiap waktu dan dalam segala situasi kondisi (Andor \& Quaye, 2014, p. 145). Pembelajaran yang dilakukan secara kontinu dapat menambah peluang bagi anak untuk menyimak apa yang diajarkan (Darmawan, 2019, p. 24). Anak menjadi lebih banyak merekam informasi yang memperkuat memorinya.

Selain itu, melihat bagaimana Musa memakai pronomina pengganti orang kedua dalam bentuk tunggal di dalam ayat 7 menyadarkan kita perintah ini disampaikan secara pribadi kepada setiap orang tua Israel (Hamilton, 2010, p. 15). Bukan hanya mengajar anak untuk menghafal ayat-ayat Alkitab dan cerita yang terdapat di dalamnya, orang Yahudi mendidik anak-anak mereka juga melalui percakapan. Apabila anak mereka bertanya tentang alasan untuk merayakan Paskah, misalnya, maka mereka perlu menjelaskannya secara detail bagaimana Allah menyelamatkan umat-Nya dari perbudakan di Mesir (Mude, 2020 , p. 65). Setiap memulai hari, ayah selaku kepala keluarga untuk mengulangi dan mendiskusikan firman Tuhan dengan anak-anak mereka. Lalu kemudian di penghujung hari, proses pengulangan juga perlu dilakukan. Dengan demikian dalam setiap kesempatan firman Tuhan bukan hanya dihafalkan, melainkan juga direnungkan, dikaji, dijelaskan, dan dirayakan (Hamilton, 2010, p. 15). Hal ini bertujuan untuk memastikan pelajaran tersebut tertanam di dalam hati dan pikiran anak.

\section{Mengajar dengan kerajinan dan keteladanan (ay. 8-9)}

Di dalam ayat 8 , umat diminta untuk mengikat perintah Tuhan di tangannya. Kata "tangan" di dalam bahasa Ibrani sering digunakan secara figuratif untuk menunjuk kepada kekuatan fisik. Selain ayat ini, kata "tangan" atau yad dalam makna figuratif "kekuatan" dapat kita jumpai di dalam Hakim-Hakim 1:35;
6:2. Penggunaan kata "tangan" dalam Ulangan 6:8 ini juga dapat diartikan mengajar anak lewat perbuatan mengingat kekuatan fisik mengacu kepada tindakan atau aksi. Oleh sebab itu, mengikat firman Tuhan pada tangan berarti memeliharanya dalam bentuk menghasilkan perbuatan yang sejalan dengan iman (Cole, 2017). Bukti nyata firman tertanam di dalam hati dan pikiran adalah ia nyata dalam perbuatan.

Dalam bahasa aslinya ayat ini tidak menyinggung soal "dahi" tetapi "mata." Seperti yang kita ketahui bersama mata adalah organ persepsi. Ini berarti ayat ini menyatakan seruan agar bangsa Israel mengikat firman Tuhan melekat dalam kehidupan mereka dan menjadikannya juga sebagai filter terhadap apa saja yang mereka persepsikan (Hamilton, 2010, p. 16).

Selain mengikatkannya di tangan dan mata, umat Tuhan juga perlu menuliskan firman Tuhan pada tiang pintu rumah dan pada pintu gerbang mereka (ay. 9). Ini berarti mengasihi Tuhan bukan hanya perlu dilakukan orang Israel sebatas di dalam lingkup keluarga atau di wilayah domestik saja, melainkan harus menjadi identitas dan tampak jelas di matamata semua orang (Harris, 2016, p. 330-331). Semua orang yang melihat mereka sepatutnya juga dapat melihat identitas dan komitmen mereka sebagai umat Tuhan.

Sebelum mengharapkan anak-anak tidak segan memproklamirkan iman mereka dalam kehidupan sehari-hari, orang tua perlu menunjukkan terlebih dahulu cara melakukannya. Pendidikan iman bukan saja soal teori atau cerita Alkitab melainkan yang paling utama adalah penghayatan. Agar anak dapat menghayati firman Tuhan, orang tua perlu terlebih dahulu memperlihatkan melalui keteladanan. Sebelum membawa anak dekat kepada Tuhan, orang tua perlu terlebih dahulu memiliki hubungan pribadi dengan Sang Pencipta. Setelah itu tercapai barulah apa yang diajarkan oleh orang tua dapat diterima oleh anak. 
Karakter seorang anak pada dasarnya merupakan hasil langsung dari apa yang orang tuanya ajarkan. Anak memiliki bakat alamiah untuk meniru atau mengikuti apa yang orang tuanya ajarkan di rumah. Itu sebabnya, pada tahap awal pertumbuhan seorang anak, kehadiran orang tua yang bijak dan beriman merupakan keharusan (Gregor, 2013, p. 119). Orang tua perlu menyediakan waktu untuk anak-anak mereka dan tidak menyerahkan sepenuhnya tanggung jawab memelihara anak kepada pengasuh.

Pendidikan iman sepatutnya dilakukan dari sedini mungkin, bahkan sejak anak masih bayi. Meskipun saat itu anak masih belum dapat menyerap perkataan secara sempurna, ia dapat menyerap tindakan dan ekspresi yang dilakukan oleh orang tuanya setiap hari (Gregor, 2013, p. 119). Dengan sendirinya anak dapat belajar dari pola hidup keseharian orang tuanya Ketika mereka melihat bagaimana orang tua berdoa, bersikap dalam pergumulan, serta berinteraksi dengan seksama.

\section{Implementasi Pendidikan Iman Anak Oleh Orang Tua Menurut Ulangan 6:1- 9 di GPdl Bangsalsari Jember}

\section{Konten Pendidikan Iman dalam Relasi dengan Tuhan}

\section{Takut akan Tuhan}

Ketika penulis meminta partisipan menjabarkan apa yang mereka ketahui tentang pendidikan iman, tidak semua narasumber dapat menjawab pertanyaan ini dengan baik. Dari delapan orang, dua partisipan menjawab pertanyaan tersebut dengan definisi iman dan tidak menjelaskan soal pendidikan. Keenam orang lainnya dapat menjawab pertanyaan ini dengan baik meski dengan pengungkapan bahasa yang berbeda. Mereka menyatakan pendidikan iman adalah pendidikan yang membentuk karakter rohani.

Pertanyaan selanjutnya adalah mengenai apa yang narasumber dapat ketahui tentang aspek-aspek pendidikan iman dalam relasinya dengan Tuhan. Jawaban semua partisipan menunjukkan bahwa dalam pandangan mereka saat teduh dan membaca Alkitab merupakan bagian dari pendidikan iman. Hanya saja meski mereka memahami hal ini beberapa mengakui tidak menerapkannya dalam kehidupan seharihari.

Semua partisipan sepemahaman mengenai ketetapan Tuhan sebagai sesuatu yang harus dilakukan. Oleh sebab itu, mereka juga meyakini ada konsekuensi bila terjadi kegagalan dalam mematuhi peraturan Tuhan. Bukan saja hubungan dengan Tuhan menjadi rusak, partisipan keenam meyakini hidup kita akan mengalami penderitaan bila tidak taat.

Mengenai arti takut akan Tuhan, rata-rata partisipan memahaminya sebagai rasa hormat yang diwujudkan dalam menghormati dan menaati firman Tuhan serta menjauhi larangan yang ditetapkan di dalam Kitab Suci. Takut akan Tuhan bagi salah satu partisipan berarti mengutamakan dan mengandalkan Tuhan dalam segala hal. Sedangkan bagi partisipan lainnya takut akan Tuhan merupakan ekspresi kasih dalam perbuatan.

Dari semua jawaban partisipan di bagian ini dapat disimpulkan mereka memiliki pemahaman yang benar tentang takut akan Tuhan. Hanya saja, jawaban mereka belum memperlihatkan penerapan yang nyata tentang takut akan Tuhan ini dalam kehidupan seharihari.

\section{Mempercayai janji Tuhan}

Pentingnya mempercayai janji Tuhan bagi tiga orang partisipan adalah untuk mendapat damai sejahtera (partisipan pertama); untuk mendapatkan pengampunan, keselamatan, hidup kekal, hikmat kebijaksanaan, kesembuhan dan kesehatan (partisipan kedua); supaya iman tidak menjadi lemah (partisipan kelima). Kelima partisipan lainnya menjawab pertanyaan ini dengan sudut pandang yang 
berbeda. Partisipan ketiga menganggap memercayai janji Tuhan itu penting karena kasihNya telah terbukti dalam hidup kita. Partisipan keempat, keenam, dan ketujuh percaya pentingnya menerima janji Tuhan karena janji-Nya adalah ya dan amin.

Dalam kaitannya dengan janji Tuhan, ketika ditanyakan bagaimana pandangan mereka tentang berkat, jawaban partisipan pertama, ketiga, keempat, keenam, ketujuh, dan kedelapan kurang lebih sama. Mereka menganggap janji berkat merupakan upah atau anugerah untuk ketaatan kita. Bagi partisipan kedua janji berkat berarti Tuhan akan selalu menyertai, melindungi, memelihara, dan mencukupkan dan partisipan kelima meyakini janji berkat mengacu kepada hidup berkelimpahan jasmani dan rohani.

Dari jawaban yang disampaikan terlihat bahwa partisipan mempercayai janji Allah yang terdapat dalam Alkitab. Mereka juga memahami bahwa mereka perlu taat untuk menikmati janji Tuhan sebagaimana yang juga digariskan di dalam Alkitab, khususnya kitab Ulangan.

\section{Mempercayai keesaan Tuhan}

Karena iman berkaitan erat dengan pemahaman maka penulis meminta partisipan menjelaskan keesaan Allah. Partisipan pertama menjawab pertanyaan ini dengan menyatakan Allah itu satu, dalam iman Kristen Bapa, Putra dan Roh Kudus pada hakikatnya adalah satu yang tidak bisa disatukan/dijamakkan dengan apa pun juga dan inilah yang di sebut tauhid. Partisipan kedua memahami keesaan Allah berarti hanya ada satu Allah. Dia adalah pencipta langit, bumi, dan alam semesta. Partisipan ketiga menjelaskan jawabannya sebagai berikut: Allah yang menciptakan seisi dunia, Allah yang telah menebus dosa semua umat manusia Allah satu-satu-Nya, Allah yang penuh kasih dan penyayang. Partisipan selebihnya menjawab pertanyaan ini kurang lebih mirip, yakni dengan menekankan Allah itu Esa atau Tunggal. Dari jawaban ini terlihat bahwa semua partisipan meyakini keesaan Allah meskipun dengan pemahaman yang sederhana.

\section{Mengasihi Tuhan dengan Segenap Hati, jiwa dan kekuatan}

Dalam menjawab pertanyaan apakah yang dimaksud dengan mengasihi Tuhan, hampir semua partisipan memiliki pemahaman yang benar, kecuali partisipan pertama yang hanya memberi jawaban singkat, yakni "menaruh kasih." Partisipan lainnya dapat menjawab pertanyaan ini dengan lebih jelas. Partisipan kedua mendefinisikan mengasihi Tuhan sebagai tindakan melakukan apa yang Tuhan inginkan sesuai dengan perintahperintah-Nya, dan kehendak-Nya. Partisipan ketiga memahami mengasihi Tuhan sebagai usaha untuk tidak menyakiti hati Tuhan dan melakukan apa yang sudah Ia perintahkan. Partisipan keempat menguraikan jawabannya sebagai berikut, "Apa pun yang kita lakukan diperhitungkan atau tidak oleh manusia jangan pesimis, lakukanlah dengan hati yang tulus dan ikhlas untuk Tuhan dengan ucapan syukur." Partisipan kelima menyatakan mengasihi Tuhan artinya hidup mau melakukan apa yang Tuhan perintahkan kepada kita, dan selalu ingin melakukan/memberikan yang terbaik buat Tuhan. Partisipan keenam menjelaskan mengasihi Tuhan sebagai melakukan segala firman Tuhan dengan segenap hati, kekuatan, pikiran kita dengan tulus dan bertanggung jawab. Semua jawaban partisipan cenderung bersifat abstrak dan tidak menunjukkan pemahaman konkret.

\section{Metode Pendidikan Iman}

\section{Mengajarkannya berulang-ulang (ay. 6-7)}

Ketika partisipan ditanya apakah mereka membiasakan diri untuk membicarakan tentang nilai-nilai kebenaran firman Tuhan dengan anak-anak mereka, lima dari delapan partisipan 
dengan mantap menjawab ya, sedangkan tiga orang lainnya tidak selalu dan kadang-kadang saja. Partisipan pertama mengaku sering bercerita tentang ketidaktaatan bangsa Israel yang kemudian mendatangkan hukuman. Ketika diminta menjabarkan apa saja yang mereka ajarkan secara berulang-ulang, rata-rata mereka mengaku menekankan soal doa, ibadah, memberi, hidup jujur, hormat kepada orang tua, mengasihi sesama.

\section{Mengajar dengan rajin dan keteladanan (ay. 8-9)}

Ayat 8 dan 9 ini dapat dimaknai sebagai pentingnya orang tua memastikan anak memahami iman dan kekristenan bukanlah semata soal doktrin melainkan cara hidup yang tampak jelas bagi setiap orang. Oleh sebab itu, keteladanan orang tua merupakan prinsip penting dalam mengajar soal iman kepada anak-anak. Dari kedelapan partisipan, partisipan kedua, keenam, ketujuh, dan kedelapan mengaku telah berusaha memberikan teladan lewat perbuatan sehari-hari terhadap anak-anak mereka. Partisipan kelima memaknai keteladanan sebagai sikap dapat mengendalikan diri di mana saja dan kapan saja serta memastikan firman Tuhan sebagai pedoman dalam bersikap. Sedangkan jawaban partisipan pertama, ketiga, dan keempat agak meleset dan tidak menyinggung soal prinsip keteladanan.

\section{KESIMPULAN}

Ulangan 6:1-9 mengingatkan kita betapa vitalnya tanggung jawab orang tua dalam mendidik iman anak. Sejak dini orang tua perlu mengajar anak-anak mereka untuk takut akan Tuhan, mempercayai janji-janji-Nya, keesaan-

\section{DAFTAR RUJUKAN}

3842. lebab. (n.d.). https://biblehub.com/nasec/ hebrew/3824.htm

Andor, J. B., \& Quaye, E. (2014). Wholistic Education and the Shema Creed (Deuteronomy 6:4-9). Research on
Nya, dan mengasihi-Nya dengan segenap hati dan jiwa. Agar pengajaran tersebut dapat tertanam dengan baik maka orang tua perlu mengajarkannya dengan rajin dan memberikan keteladanan dalam kehidupan sehari-hari.

Dari hasil observasi dan wawancara yang dilakukan, penulis mendapati bahwa para orang tua di Bangsalsari menyadari dan memahami tanggung jawab mereka dalam mendidik iman anak-anak mereka. Namun, pengetahuan mereka masih bersifat mendasar dan kurang memadai. Setidaknya bagi beberapa orang di antaranya. Hal ini terlihat di poin terakhir di mana beberapa partisipan kurang dapat menjelaskan prinsip keteladanan hidup dalam mendidik. Untuk dapat menghasilkan keteladanan hidup orang tua perlu dewasa secara rohani terlebih dahulu. Tingkat kedewasaan rohani seseorang ditentukan oleh sejauh mana ia memahami firman Tuhan dan menerapkannya dalam kehidupan sehari-hari.

Penulis menyarankan agar gereja memasukkan pembekalan rohani terhadap para orang tua sebagai bagian dari program utama untuk memperlengkapi orang tua lebih maksimal dalam menjalani perannya. Pembekalan rohani yang dimaksud di sini adalah program khusus, yang bersifat mendampingi orang tua dalam menerapkan Pendidikan rohani kepada anak-anak mereka. Karena hasil penelitian ini setidaknya menyiratkan mendengarkan khotbah saja masih belum cukup memadai sebagai sarana pembekalan kerohanian orang tua. Oleh sebab itu, penulis merekomendasikan penulisan lanjutan yang menyelidiki peran dan praktik gereja dalam mendidik generasi muda melalui orang tua mereka.

Humanities and Social Sciences, 4(27), 143148.

Biddle, M. E. (2003). Smyth \& Helwys Bible Commentary - Deuteronomy. Smyth \& Helwys Publishing.

Bunge, M. (2009). Biblical and Theological 
Perspectives: Resources for Raising Children in the Faith. Lutheran Partners, 25(4), 16-21.

Cole, S. J. (2017). 10. Raising Godly Generations (Deuteronomy 6:1-25). https://bible.org/ seriespage/10-raising-godly-generationsdeuteronomy-61-25

Craigie, P. C. (1976). The Book of Deuteronomy New International Commentary on the Old Testament). Eerdmans.

Darmawan, I. P. A. (2019). Pembelajaran Memorisasi dalam Ulangan 6: 6-9. Jurnal Teologi Dan Pelayanan Kristiani: EPIGRAPHE, 3(1), 21-27.

Easton, M. G. (n.d.). Faith. https:// eastonsbibledictionary.org/1302Faith.php.

Gregor, H. (2013). Theology of Parenting: Is Parenting in Crisis Today? Biblijski Pogledi, 21(1-2), 115-130.

Grisanti, M. A. (2012). Deuteronomy: The Expositor's Bible Commentary. Zondervan.

Hamilton, J. M. J. (2010). That the Coming Generation Might Praise The Lord. The Journal of Family Ministry, 1(1), 12-18.

Harris, S. L. (2016). Between Text and Sermon Deuteronomy 6:4-9. Interpretation: $A$ Journal of Bible and Theology, 70(3), 329331. 10.1177/0020964316640509 https://doi.org/

Ismaniar \& Setiyo, U. (2020). "Mirror Effect" dalam Perkembangan Perilaku Anak di Masa Pandemi Covid 19. DIKLUS: Jurnal Pendidikan Luar Sekolah, 4(2), 147-157. https://journal.uny.ac.id/index.php/ jurnaldiklus/article/view/32429/14306.

Kumar, R. (2011). Research Methodology: A StepBy-Step for Beginners (Third). SAGE Publications.

Ludji, B. (2009). Pemahaman Dasar Perjanjian
Lama 1. Bina Media Informasi.

Mardiharto. (2019). Pola Asuh Pendidikan Kerohanian Pada Anak. PASCA: Jurnal Teologi Dan Pendidikan Agama Kristen, 15(1), 23-27.

Martana, S. P. (2006). Problematika Penerapan Metode Field Research untuk Penelitian Arsitektur Vernakular di Indonesia. Dimensi Teknik Arsitektur, 34(1), 59-66.

Mude, E. (2020). Cyber Parenting In Society 5.0. INTEGRITAS: Jurnal Teologi, 2(1), 6176. http://journal.sttjaffrayjakarta.ac.id/ index.php/JI

Pantan, F. \& Benyamin, P. I. (2020). Peran Keluarga dalam Pendidikan Anak pada Masa Pandemi Covid-19. KHARISMATA, 3(1), 13-24.

Pazmiño, R. W. (2010). Christian Education is More than Formation. Christian Education Journal: Research on Educational Ministry, 7(2), 356-365. https://doi.org/ 10.1177/073989131000700208

Rantesalu, S. B. (2018). Kompetensi Pedagogik Menurut Analisis Ulangan 6:7-9 dengan Pendekatan Hermeneutik Schleiermacher. BIA': Jurnal Teologi Dan Pendidikan Kristen Kontekstual, 1(2), 153-163.

Utami, N. T. (2017). Tinjauan Terhadap Prinsip-Prinsip Pengajaran Anak Berdasarkan Ulangan 6:1-19. Logon Zoes, 1(1), 108-123.

Wagiu, N. P. (2020). Implementasi Peran Orang Tua Menurut Ulangan 6:4-9 dalam Pendidikan Agama Kristen Keluarga di Gereja Masehi Injili di Minahasa Jemaat Imanuel Aertembaga Bitung. Shanan, 4(2), 128-161.

Woods, E. J. (2011). Deuteronomy: An Introduction and Commentary. InterVarsity Press. 